\title{
Sex Differences in the Rapid Cell Signaling Mechanisms Underlying the Memory-Enhancing Effects of $17 \beta$-Estradiol
}

\author{
DWendy A. Koss, ${ }^{1}$ Jacqueline M. Haertel, ${ }^{1}{ }^{\circledR}$ Sarah M. Philippi, ${ }^{1}$ and ${ }^{\circledR}$ Karyn M. Frick ${ }^{1}$
}

https://doi.org/10.1523/ENEURO.0267-18.2018

${ }^{1}$ Department of Psychology, University of Wisconsin-Milwaukee, Milwaukee, WI 53211

\section{Visual Abstract}

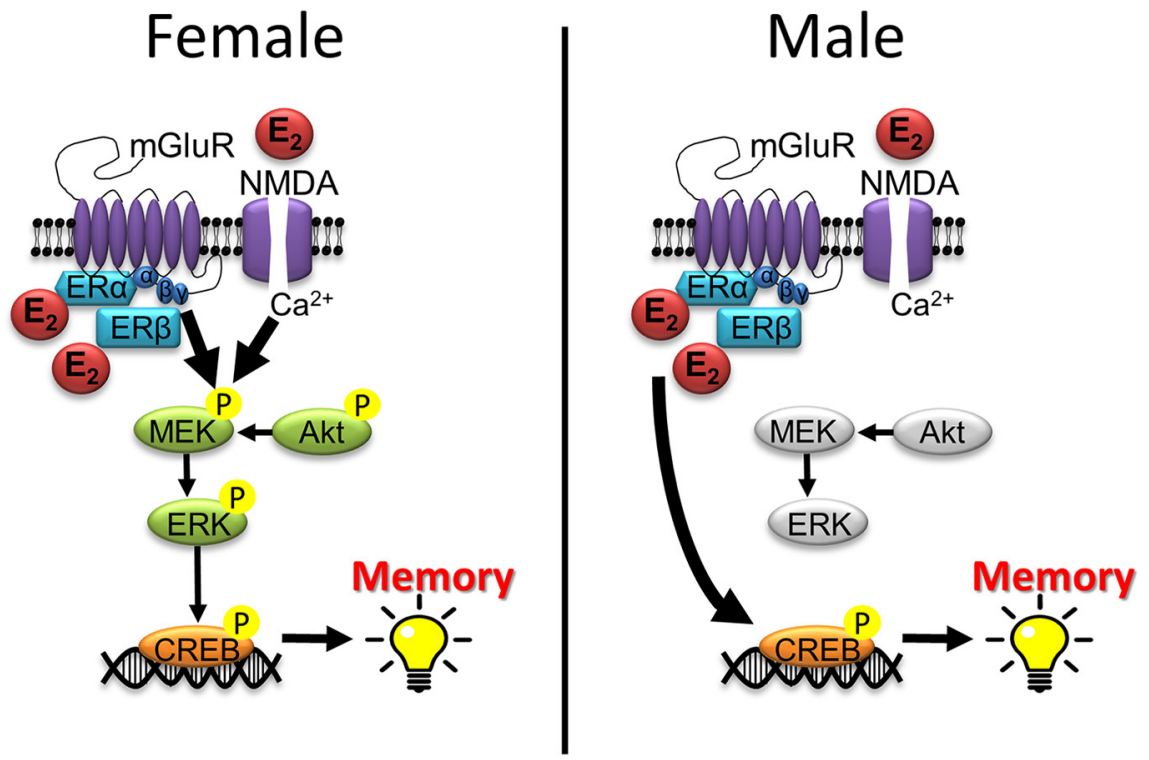

Little is known about how $17 \beta$-estradiol $\left(E_{2}\right)$ mediates memory formation in males. In ovariectomized (OVX) mice, bilateral dorsal hippocampal $(\mathrm{DH})$ infusion of $\mathrm{E}_{2}$ enhances memory consolidation in object recognition (OR) and object placement (OP) tasks in a manner dependent on activation of extracellular signal-regulated kinase (ERK) and Akt signaling. Here, bilateral $\mathrm{DH}_{2}$ infusion enhanced memory consolidation in both tasks among OVX female, gonadally-intact male, and castrated male mice, suggesting comparable facilitation of memory consoli-

\section{Significance Statement}

The impact of biological sex on neural function is understudied, despite clear sex differences in the risks and symptomology of disorders such as Alzheimer's disease, mood disorders, developmental learning disabilities, and attention-deficit disorder. The ability of $17 \beta$-estradiol $\left(E_{2}\right)$ to enhance memory consolidation in females depends on rapid activation of cell signaling pathways in the dorsal hippocampus (DH), yet the mechanisms underlying its effects in males are unknown. The present study suggests a novel sex difference in the hippocampal cell-signaling mechanisms through which $\mathrm{E}_{2}$ facilitates memory consolidation. These and future studies may lead to the development of sex-specific therapeutics that more effectively reduce cognitive dysfunction in diseases that disproportionately affect one sex or the other. 
dation in both sexes, independent of testicular hormones in males. Contrary to previous reports in OVX mice, $E_{2}$ did not increase DH ERK or Akt phosphorylation in males, nor did the ERK inhibitor U0126 [1,4-diamino-2,3dicyano-1,4-bis (o-aminophenylmercapto) butadiene] prevent $E_{2}$ from enhancing memory consolidation among intact and castrated males. These data suggest that ERK activation is not necessary for $E_{2}$ to enhance memory consolidation in males, and compared with previous reports in females, reveal novel sex differences in the cell-signaling pathways through which $\mathrm{E}_{2}$ facilitates memory consolidation. To explore the mechanisms underlying $E_{2}$-induced memory enhancements in males, phosphorylation of the transcription factor cAMP response element binding protein (CREB) in the DH was assessed. $\mathrm{E}_{2}$ increased phospho-CREB levels in both sexes, yet U0126 did not block these increases in castrated or intact males, indicating that $E_{2}$ regulates CREB phosphorylation in males via an ERK-independent mechanism. Collectively, these findings suggest that the beneficial effects of hippocampal $E_{2}$ on memory consolidation in males and females are mediated by different molecular mechanisms, which has important implications for the development of treatments to reduce memory dysfunction in men and women.

\section{Key words: ERK; hippocampus; memory consolidation; object recognition; spatial memory}

\section{Introduction}

Interest in sex differences is on the rise, perhaps due to the National Institutes of Health mandate that sex be considered as a biological variable in research proposals. Unlike most areas of neuroscience, in which male subjects predominate, females have typically been the focus of studies examining hormonal regulation of cognition. Ample evidence demonstrates that $17 \beta$-estradiol $\left(E_{2}\right)$ given to ovariectomized (OVX) rat and mice enhances object recognition (OR) and spatial memory consolidation (Tuscher et al., 2015; Sheppard et al., 2018). Numerous receptor, cell-signaling, and epigenetic mechanisms necessary for these effects have been identified (Frick, 2015; Frick et al., 2015, 2018; Galea et al., 2017). In contrast, the effects of $E_{2}$ on memory processes in male rodents have not been well studied, and the mechanisms underlying these effects are scarcely known.

Studies using various spatial tasks have demonstrated that pre-training $\mathrm{E}_{2}$ administration improves spatial learning and memory among intact and gonadectomized (GDX) male rodents (Luine and Rodriguez, 1994; Heikkinen et al., 2002; Gibbs, 2005; Gibbs and Johnson, 2008; McConnell et al., 2012; Locklear and Kritzer, 2014). In studies using acute post-training treatments to pinpoint effects of $E_{2}$ on spatial memory consolidation, systemic administration

Received July 10, 2018; accepted September 30, 2018; First published October 16, 2018.

The authors declare no competing financial interests.

Author contributions: W.A.K. and K.M.F. designed research; W.A.K., J.M.H., and S.M.P. performed research; W.A.K. analyzed data; W.A.K. and K.M.F. wrote the paper.

This work was supported by National Institutes of Health Grant R01MH107886, a Research Growth Initiative Award from the University of Wisconsin-Milwaukee Research Foundation (101X334), the University of Wisconsin-Milwaukee College of Letters \& Science, and the University of Wisconsin-Milwaukee Office of Undergraduate Research.

Acknowledgements: We thank Lisa Taxier, Dr. Jaekyoon Kim, Miranda Schwabe, and Dr. Kellie Gross for helpful comments on this manuscript. We also thank Rachel Gremminger for assisting with behavioral testing.

Correspondence should be addressed to Dr. Karyn M. Frick, Department of Psychology, University of Wisconsin-Milwaukee, 2441 East Hartford Avenue, Milwaukee, WI 53211, E-mail: frickk@uwm.edu.

https://doi.org/10.1523/ENEURO.0267-18.2018

Copyright (c) 2018 Koss et al.

This is an open-access article distributed under the terms of the Creative Commons Attribution 4.0 International license, which permits unrestricted use, distribution and reproduction in any medium provided that the original work is properly attributed. enhanced consolidation in an object placement (OP) task among GDX male rats (Jacome et al., 2016), and dorsal hippocampal $(\mathrm{DH})$ infusion enhanced consolidation in the Morris water maze among intact male rats (Packard et al., 1996). Although evidence is limited, these few studies suggest that $E_{2}$ facilitates memory consolidation in males as it does in females. However, unlike females, the mechanisms through which $E_{2}$ enhances memory in males are unclear.

The male hippocampus expresses all three major estrogen receptors $(\mathrm{ER} \alpha, \mathrm{ER} \beta$, and GPER; Milner et al., 2001, 2005; Mitterling et al., 2010; Waters et al., 2011, 2015), but sex differences in ER distribution are observed within dendritic spines (Gillies and McArthur, 2010). In OVX rats and mice, acute administration of $E_{2}$ systemically or into the $\mathrm{DH}$ rapidly increases $\mathrm{CA} 1$ dendritic spine density, an effect that depends on phosphorylation of extracelluar signal-regulated kinase (ERK) and downstream mammalian target of rapamycin (mTOR) signaling (Inagaki et al., 2010; Tuscher et al., 2016a). Similarly, activation of ERK and other signaling pathways is necessary for $E_{2}$ to increase CA1 spine density in adult male hippocampal slices (Murakami et al., 2006; Mukai et al., 2007). Because $E_{2}$ enhances memory consolidation in both sexes, and ERK phosphorylation is necessary for $\mathrm{E}_{2}$-induced memory consolidation in OVX females (Boulware et al., 2013), ERK activation could be involved in the mnemonic effects of $E_{2}$ in males. However, $E_{2}$ administered to neonatal rat hippocampal cultures induces ERKdependent phosphorylation of the transcription factor cAMP response element binding protein (CREB) in female-derived cultures, but not cultured tissue from males (Boulware et al., 2005), suggesting potential sex differences in $\mathrm{E}_{2}$-induced $\mathrm{ERK}$ phosphorylation. As such, the extent to which estrogenic regulation of memory in males might depend on ERK activation is unclear.

Given the many gaps in the male literature, this study was designed to determine whether $\mathrm{DH} \mathrm{E}_{2}$ infusion affects memory consolidation and DH ERK phosphorylation in adult male mice. We first compared effects of posttraining $E_{2}$ on object recognition and spatial memory consolidation in intact male and OVX female mice. $E_{2}$ enhanced consolidation of both types of memory in both sexes, but only increased phosphorylation of p42 ERK and upstream Akt in females. Moreover, inhibiting ERK 
phosphorylation did not block the memory-enhancing effects of $E_{2}$ in males, suggesting that $E_{2}$-induced memory enhancement in intact males does not depend on DH ERK activation. To determine whether testicular hormones affect this sex difference, we compared effects of $E_{2}$ on memory consolidation and phosphorylation of ERK and Akt in GDX and intact males. As before, $E_{2}$ enhanced memory consolidation without affecting ERK or Akt, and ERK inhibition did not block $E_{2}$ 's mnemonic effects. However, $E_{2}$ increased CREB phosphorylation in both sexes, and this effect was not blocked by ERK inhibition in males, suggesting that $E_{2}$ may regulate memory in males via ERK-independent CREB phosphorylation.

\section{Materials and Methods}

\section{Subjects}

Female and male mice were obtained from Taconic Biosciences at nine weeks of age. Mice were maintained on a $12 / 12$ h light/dark cycle with ad libitum access to food and water. Mice underwent surgeries at 10 weeks of age and behavioral testing began at $\sim 11-15$ weeks of age. Mice were group-housed until surgery, after which point they were single housed. All procedures followed the National Institutes of Health Guidelines for the Care and Use of Laboratory Animals and were approved by the Institutional Animal Care and Use Committee of the University of Wisconsin-Milwaukee.

\section{Surgeries}

Mice were administered $5 \%$ isoflurane in $100 \%$ oxygen for anesthesia induction and then maintained at 2-3\% isoflurane throughout surgery. All mice underwent a twostep surgical procedure in which they were first OVX, GDX, or sham GDX and were then implanted intracranially with chronic indwelling guide cannulae. All females were OVX as described previously (Boulware et al., 2013; Kim et al., 2016; Tuscher et al., 2016a). Briefly, bilateral incisions were made on each side of the lower dorsal flanks, followed by an incision in each underlying muscle wall. Each side of the fallopian tubes was ligated and ovaries were removed. Muscle wall incisions were sutured and skin incisions were closed with wound clips. In experiments where males were compared to females, males were left gonadally-intact but underwent similar anesthesia and bilateral incisions as females. In experiments comparing gonadally-intact (sham) males to GDX males, intact males underwent similar anesthetic and procedures as GDX males. During male GDX surgeries, a midline incision was made on the scrotal sac, testes were isolated and carefully separated from fat, and then the testes were tied off at the vas deferens and spermatic artery with chromic gut and the testes were removed. The incision was closed with monofilament sutures.

Immediately following sham and GDX procedures, all mice were implanted with chronic indwelling guide cannulae as described previously (Boulware et al., 2013; Fortress et al., 2013; Kim et al., 2016). Mice were secured in a stereotaxic apparatus (Kopf Instruments) and implanted with bilateral guide cannulae (22 gauge; C232G, Plastics One Inc.) aimed at each hemisphere of the $\mathrm{DH}$
$(-1.7 \mathrm{~mm} \mathrm{AP}, \pm 1.5 \mathrm{~mm} \mathrm{ML},-2.3 \mathrm{~mm} \mathrm{DV})$ or with triple guide cannulae aimed at both hippocampi and the dorsal third ventricle (intracerebroventricular; $-0.9 \mathrm{~mm} \mathrm{AP}, \pm 0.0$ $\mathrm{mm} \mathrm{ML},-2.3 \mathrm{~mm}$ DV). Dummy cannulae (C232DC, Plastics One Inc.) were inserted into all guide cannulae to maintain patency. Cannulae were fixed to the skull with dental cement (Darby Dental Supply) that served to close the wound.

\section{Drugs and infusions}

Infusions were performed by gently restraining mice, removing the dummy cannulae, and placing an infusion cannula into the guide cannulae (C313l; DH: 28 gauge, extending $0.8 \mathrm{~mm}$ beyond the $1.5 \mathrm{~mm}$ guide; intracerebroventricular, 28 gauge, extending $1.0 \mathrm{~mm}$ beyond the $1.8 \mathrm{~mm}$ guide). The infusion cannula was attached to PE50 polyethylene tubing that was mounted on a $10-\mu l$ Hamilton syringe. Infusions were controlled by a microinfusion pump (KDS Legato 180, KD Scientific) and conducted immediately post-training at a rate of $0.5 \mu \mathrm{l} / \mathrm{min}$ into the $\mathrm{DH}$ or $1 \mu \mathrm{l} / 2 \mathrm{~min}$ into the dorsal third ventricle as described previously (Boulware et al., 2013; Fortress et al., 2013, 2014; Kim et al., 2016). Infusion cannulae remained in place for $1 \mathrm{~min}$ after each infusion to prevent diffusion back up the cannula track. For studies in which $E_{2}$ was infused in combination with the ERK phosphorylation inhibitor U0126 [1,4-diamino-2,3-dicyano-1,4-bis (oaminophenylmercapto) butadiene], the inhibitor was first infused bilaterally into the $\mathrm{DH}$ and then $\mathrm{E}_{2}$ was infused to the dorsal third ventricle. This triple infusion protocol prevents possible damage to the $\mathrm{DH}$ from two infusions in rapid succession (Fernandez et al., 2008; Zhao et al., 2010, 2012; Boulware et al., 2013; Fortress et al., 2013).

Cyclodextrin-encapsulated $E_{2}$ (Sigma-Aldrich Corp.) was dissolved in $0.9 \%$ saline and infused at doses of 5 $\mu \mathrm{g} /$ hemisphere into the $\mathrm{DH}$ or $10 \mu \mathrm{g}$ into the dorsal third ventricle. The vehicle, 2 -hydroxypropyl- $\beta$-cyclodextrin (HBC; Sigma- Aldrich Corp.) dissolved in 0.9\% saline, was used at the same concentration as encapsulated $\mathrm{E}_{2}$ (Zhao et al., 2012; Boulware et al., 2013). DH or intracerebroventricular infusion of these $E_{2}$ doses enhances both OR and OP memory consolidation in OVX mice (Zhao et al., 2010, 2012; Boulware et al., 2013; Fortress et al., 2013; Kim et al., 2016). The ERK phosphorylation inhibitor U0126 (Promega Corp.) was dissolved in 50\% DMSO and infused at doses of $0.25,0.5$, or $1 \mu \mathrm{g} /$ hemisphere into the $\mathrm{DH}$. The vehicle control for U0126 was 50\% DMSO in $0.9 \%$ saline. In OVX mice, bilateral $\mathrm{DH}$ infusion of $1 \mu \mathrm{g}$, but not 0.1 or $0.5 \mu \mathrm{g}$, U0126 impairs OR memory consolidation (Fernandez et al., 2008), and DH infusion of $0.5 \mu \mathrm{g}$ does not impair OP memory consolidation (Boulware et al., 2013). Because $0.5 \mu \mathrm{g} /$ hemisphere U0126 has no detrimental effects on memory consolidation tested in either task, we previously infused this dose into the $\mathrm{DH}$ of OVX mice in conjunction with an intracerebroventricular infusion of $10 \mu \mathrm{g} \mathrm{E}_{2}$ and found that U0126 blocked the memory-enhancing effects of $E_{2}$ in both tasks (Fernandez et al., 2008; Fortress et al., 2013). Here, we used these data as a guide for experiments in intact and GDX males to identify a behaviorally subeffective dose of U0126 
that could be used to determine whether the memoryenhancing effects of $E_{2}$ in males depend on ERK activation.

\section{OP and OR tasks}

Approximately one week after surgery, mice began OP and OR testing to assess spatial and OR memory consolidation, respectively, as described previously (Fernandez et al., 2008; Fan et al., 2010; Zhao et al., 2010, 2012; Boulware et al., 2013; Fortress et al., 2013). Memory in both tasks depends on intact function of the DH (Baker and Kim, 2002; Cohen et al., 2013) and administration of $\mathrm{E}_{2}$ immediately, but not $3 \mathrm{~h}$, after training enhances memory consolidation in both tasks among young adult and middle-aged OVX mice (for review, see Tuscher et al., 2015). As in previous work (Tuscher et al., 2015), all treatments in this study were administered immediately after training to pinpoint effects on the consolidation phase of memory formation.

All mice were tested in both the OP and OR tasks, the order of which was counterbalanced within each group. OP testing, OR testing, and brain tissue collection were separated by two weeks to allow acute effects of each infusion to dissipate before the next infusion. Before the start of behavioral testing, mice were handled for $3 \mathrm{~d}$ and then habituated to the testing arena $(60 \times 60 \times 47 \mathrm{~cm}$ high) for $5 \mathrm{~min} / \mathrm{d}$ for $2 \mathrm{~d}$. During habituation, mice moved about freely in the apparatus without objects present. During both handling and habituation, mice were acclimated to objects by placing a Lego Duplo brick $(6.3 \times 3.1$ $\times 2.3 \mathrm{~cm}$ ) in their home cage. Following habituation, mice were trained in either OP or OR. Mice were first briefly rehabituated to the arena by placing them inside without any objects for $2 \mathrm{~min}$, after which they were returned to their home cage while two identical objects were placed in the northwest or northeast corners of the arena. Mice were then returned to the arena and allowed to explore the objects, which included a plumbing valve, chip clip, mini-stapler, date stamp, master lock, and aquarium figurines. To ensure that all mice received the same amount of exposure to the objects, trials were not ended until mice had accumulated $30 \mathrm{~s}$ of object exploration or after a maximum of $20 \mathrm{~min}$. Object exploration was scored only when the mouse's nose or front paws contacted an object. Immediately after the completion of the training session, mice were infused and then returned to their home cages.

Testing occurred $24 \mathrm{~h}$ later for OP and $48 \mathrm{~h}$ later for OR. During OP testing, one training object was moved to the southwest or southeast corner of the arena. During OR testing, one training object was replaced with a novel object. In both tasks, mice were required to explore the objects until they accumulated of $30 \mathrm{~s}$ of exploration. Time spent with the objects was recorded using ANYmaze tracking software (ANY-maze, RRID:SCR_014289). Mice that remember the identity and location of the training objects should spend more time than chance with the moved and novel objects. Chance is designated as $15 \mathrm{~s}$ because this value represents equal exploration of both objects, and hence, no memory of the training objects. The 24- and 48-h delays were used for OP and OR, re- spectively, based on previous evidence from OVX females that vehicle-treated mice do not show intact memory at 24 and $48 \mathrm{~h}$ after OP and OR training, respectively (Boulware et al., 2013; Fortress et al., 2015; Kim et al., 2016). Similarly, gonadally-intact males can remember object identity $24 \mathrm{~h}$ after OR training (Frick and Gresack, 2003; Fortress et al., 2013). Thus, the 24- and 48-h delays were used for OP and $\mathrm{OR}$, respectively, to permit observation of potential memoryenhancing effects of $E_{2}$. To test for impairing effects of U0126, delays were set at $4 \mathrm{~h}$ for the OP task and $24 \mathrm{~h}$ for OR. These delays were chosen because vehicle-treated OVX mice exhibit intact memory using these delays between training and testing (Boulware et al., 2013; Fortress et al., 2015; Kim et al., 2016).

\section{Western blotting}

Two weeks after the conclusion of behavioral testing, mice were infused with vehicle or $\mathrm{E}_{2}$ and then cervically dislocated and decapitated 5 min later. The $\mathrm{DH}$ was then bilaterally dissected by carefully removing the overlying cortex and cutting the hippocampus horizontally at the level of the base of the superior colliculus. After severing the fornix, $\mathrm{DH}$ tissue was excised using forceps and stored at $-80^{\circ} \mathrm{C}$ until homogenization. Western blotting was then performed as described previously by our laboratory (Boulware et al., 2013; Fortress et al., 2015; Kim et al., 2016). Tissue was homogenized in lysis buffer containing PMSF and a protease inhibitor cocktail (Sigma-Aldrich Corp.) using a sonicator (Sonifier 250, Branson Ultrasonics). Protein concentrations were measured using a Bradford assay (Bio-Rad Laboratories) and aliquots were prepared containing $2 \mu \mathrm{g} / \mu \mathrm{l}$ of protein. Proteins were electrophoresed on 10\% TGX stain-free precast gels (Bio-Rad Laboratories) and transferred to PVDF membranes (Bio-Rad Laboratories). To verify protein transfer, total protein in each lane was visualized on a ChemiDoc MP gel imager (Bio-Rad Laboratories). Membranes were then blocked in 5\% milk in 0.1\% Tween 20 in Tris-buffered saline (TTBS) and incubated in primary antibodies overnight at $4^{\circ} \mathrm{C}$. All primary antibodies were purchased from Cell Signaling Technologies (phosphoERK \#9101S, RRID:AB_331646 and total-ERK \#9102S, RRID:AB_330744, 1:2000; phospho-AKT \#9271S, RRID: AB_329825 and total AKT \#4691S, RRID:AB_915783, 1:1000; phospho-CREB \#9198S, RRID:AB_2561044, 1:750) and diluted in 5\% BSA/TTBS. Blots were then incubated for $1 \mathrm{~h}$ at room temperature with a rabbit HRP-conjugated secondary antibody (Cell Signaling Technologies \#7074S, RRID:AB_2099233; 1:15000 for ERK antibodies; 1:5000 for CREB and AKT) and developed using Clarity Max chemiluminescent substrate (Bio-Rad Laboratories). The ChemiDoc MP imager was used to detect the chemiluminescent signal. Densitometry was performed using Image Lab software (Bio-Rad Laboratories Image Lab v 5.2, RRID:SCR_014210). Both ERK (p44 and p42 isoforms) and Akt were normalized to their respective total protein and expressed as \% immunoreactivity to vehicle. Phospho-CREB was normalized to total amount of protein transferred in each corresponding lane and expressed in \% immunoreactivity to vehicle of the same sex. In experiments using U0126, \% immunoreactivity 
was expressed relative to the group that received vehicle infusions into both the $\mathrm{DH}$ and dorsal third ventricle (vehicle/ vehicle group).

\section{Experimental design and statistical analysis Experiment 1}

This experiment examined effects of $E_{2}$ on memory consolidation in OVX female and sham GDX male mice. A $2 \times 2$ design was used with sex and treatment (vehicle vs $E_{2}$ ) as between-subjects variables tested in a two-way ANOVA. One-sample $t$ tests were also performed between each group mean and the hypothetical mean of 15 $s$ (chance performance) to assess learning within each group. Female mice were OVX and males were sham GDX immediately before being implanted with bilateral $\mathrm{DH}$ guide cannulae. Immediately after training in OR and OP, mice received $\mathrm{DH}$ infusion of vehicle (OR: male, $n=20$, female, $n=18$; OP: male, $n=22$, female, $n=18$ ) or $\mathrm{E}_{2}$ (OR: male, $n=22$, female, $n=18$; OP: male, $n=20$, female, $n=17$ ) and were tested as described above. Two weeks after the completion of behavioral testing, the intact males and OVX females received bilateral $\mathrm{DH}$ infusions of vehicle (male, $n=14$; female, $n=14$ ) or $\mathrm{E}_{2}$ (male, $n=17$; female, $n=18$ ) and $\mathrm{DH}$ tissue was collected $5 \mathrm{~min}$ later for Western blot analysis of ERK phosphorylation. A subset of these brains ( $n=6$ /group) was also assayed for Akt and CREB phosphorylation.

\section{Experiment 2}

This study tested effects of $E_{2}$ on memory consolidation in sham GDX and GDX male mice. A $2 \times 2$ design was used, with surgery (sham or GDX) and treatment (vehicle vs $E_{2}$ ) as between-subjects variables tested in a two-way ANOVA. One-sample $t$ tests were also performed to assess within-group learning. Males received sham GDX or GDX surgery immediately before bilateral cannula implanation surgery. Mice received vehicle (OR: sham, $n=10$, GDX, $n=9$; OP: sham, $n=10$, GDX, $n=10$ ) or $\mathrm{E}_{2}$ (OR: sham, $n=9$, GDX, $n=8$; OP: sham, $n=9$, GDX, $n=11$ ) infusion immediately after $\mathrm{OR}$ and $\mathrm{OP}$ training and were tested as described above.

\section{Experiment 3}

Vehicle or one of three doses of the ERK phosphorylation inhibitor U0216 were infused into the DH to identify a dose that would not impair memory on its own in a subsequent co-infusion experiment with $E_{2}$. U0126 prevents the upstream kinase MAP kinase (MAPK) kinase (MEK) from phosphorylating ERK. Male mice were GDX and implanted with bilateral $\mathrm{DH}$ cannulae. Immediately after $\mathrm{OR}$ and $\mathrm{OP}$ training, mice received $\mathrm{DH}$ infusion of $50 \%$ DMSO vehicle (OR: $n=10$; OP: $n=10$ ) or U0126 in doses of $0.25 \mu \mathrm{g} /$ hemisphere (OR: $n=9$; OP: $n=6$ ), 0.5 $\mu \mathrm{g} /$ hemisphere (OR: $n=8$; OP: $n=8$ ), or $1 \mu \mathrm{g} / \mathrm{hemi-}$ sphere (OR: $n=7$; OP: $n=8$ ). A one-way ANOVA was performed to assess differences among the groups, and one-sample $t$ tests assessed within-group learning.

\section{Experiments $4 a$ and $4 b$}

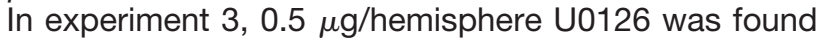
to have no effect on memory in either behavioral task, and so was used here to determine whether ERK phosphory- lation is necessary for the memory-enhancing effects of $\mathrm{E}_{2}$ in sham GDX (experiment $4 \mathrm{a}$ ) and GDX males (experiment $4 b$ ). Both studies used $2 \times 2$ designs in which hormone treatment (vehicle or $\mathrm{E}_{2}$ ) and inhibitor treatment (vehicle or U0126) were the between-subjects variables in two-way ANOVAs. Again, one-sample $t$ tests assessed learning within each group. Immediately after training, mice were infused with vehicle or $0.5 \mu \mathrm{g} /$ hemisphere $\mathrm{U} 0126$ into the $\mathrm{DH}$ and vehicle or $10 \mu \mathrm{g} \mathrm{E}_{2}$ into the dorsal third ventricle. In experiment $4 a$, samples sizes for sham GDX mice were as follows for OR (vehicle + vehicle: $n=8$; vehicle+U0126: $n=8$; $\mathrm{E}_{2}$ +vehicle: $n=9 ; \mathrm{E}_{2}+$ U0126: $n=$ 10) and OP (vehicle+vehicle: $n=5$; vehicle+U0126: $n=$ 5; $\mathrm{E}_{2}+$ vehicle: $n=7 ; \mathrm{E}_{2}+$ U0126: $n=7$ ). In experiment $4 \mathrm{~b}$, samples sizes for GDX mice were as follows for OR (vehicle+vehicle: $n=13$; vehicle+U0126: $n=6 ; \mathrm{E}_{2}+$ vehicle: $n=11 ; \mathrm{E}_{2}+$ U0126: $n=9$ ) and OP (vehicle + vehicle: $n=7$; vehicle + U0126: $n=7 ; \mathrm{E}_{2}+$ vehicle: $n=$ 8; $\mathrm{E}_{2}+$ U0126: $n=9$ ). Testing was conducted as described above. Two weeks later, mice were infused again and the $\mathrm{DH}$ dissected for Western blot analysis of ERK ( $n$ $=6 /$ group), Akt ( $n=6 /$ group), and CREB levels ( $n=$ 5-6/group).

\section{Statistical analyses}

For all behavioral experiments, two statistical analyses were performed using GraphPad Prism 6 software (RRID: SCR_002798; Kim et al., 2016; Tuscher et al., 2016b; Kim and Frick, 2017). To assess learning within each group, one-sample $t$ tests compared exploration time for each group with chance (set at $50 \%$ or $15 \mathrm{~s}$ ). More time spent with the moved or novel object indicated intact memory for the location and identity, respectively, of the training objects. To assess effects of sex and treatment among the groups, one- or two-way ANOVAs were performed, followed by Fisher's LSD post hoc tests for significant interactions when necessary. Similar ANOVA and post hoc analyses were conducted for Western blotting data. Significance was defined at $p<0.05$.

\section{Results}

\section{$E_{2}$ enhances memory consolidation in gonadally- intact males and OVX females}

In OVX females, $\mathrm{DH}$ infusion of $E_{2}$ consistently enhances 24-h OP and 48-h OR memory consolidation (Tuscher et al., 2015; Frick et al., 2018). To explore potential sex differences in the memory-enhancing effects of DH $E_{2}$ infusion, OVX females and sham GDX males received bilateral DH infusion of vehicle or $5 \mu \mathrm{g} / \mathrm{hemisphere}$ $E_{2}$ immediately after training in both object tasks (experiment 1). Two-way ANOVAs revealed significant main effects of $\mathrm{E}_{2}$ treatment for both OP $\left(F_{(1,69)}=48.79, p<\right.$ 0.0001 ; Fig. $1 A)$ and $\mathrm{OR}\left(F_{(1,73)}=18.27, p<0.0001\right.$; Fig. $1 B$ ), indicating that vehicle groups differed significantly from $E_{2}$-treated groups in both tasks. The main effect of sex and sex $\times$ treatment interaction were not significant, suggesting similar memory-enhancing effects of $E_{2}$ in both sexes. These data are supported by the results of one-sample $t$ tests, which assess whether the time each group spent with the moved or novel object differs relative 

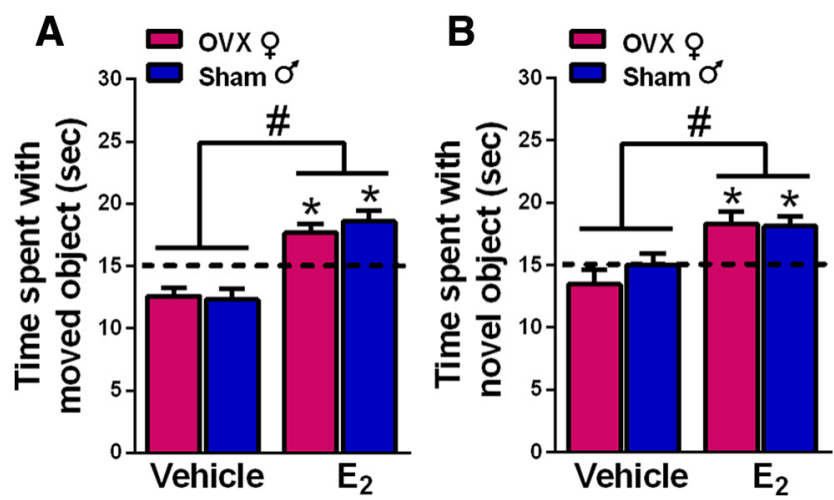

Figure 1. Infusion of $E_{2}$ into the $\mathrm{DH}$ enhanced spatial and $\mathrm{OR}$ memory consolidation in both sexes in the OP $(\boldsymbol{A})$ and OR $(\boldsymbol{B})$ tasks. OVX female and sham GDX male mice were infused with $E_{2}$ immediately after OP and OR training. Both female and male mice treated with $E_{2}$ investigated the moved $(\boldsymbol{A})$ or novel $(\boldsymbol{B})$ object more than chance $(* p<0.05$; chance $=$ dashed line at 15 s). $E_{2}$-treated groups also interacted with the moved or novel object significantly more than same-sex vehicle-treated mice (\#p $<0.05)$. Each bar represents the mean $+/-$ standard error of the mean (SEM).

to the chance value of $15 \mathrm{~s}$. In OP, $\mathrm{E}_{2}$-treated groups of both sexes spent significantly more time exploring the displaced object than chance (male, $t_{(18)}=4.16, p=$ 0.003 ; female, $t_{(15)}=3.63, p=0.003$ ), whereas vehicleinfused groups spent significantly less time than chance exploring the moved object (male, $t_{(19)}=3.06, p=0.006$; female, $\left.t_{(17)}=3.44, p=0.003\right)$. In OR, $E_{2}$-treated mice of both sexes interacted with the novel object significantly more than chance (male, $t_{(21)}=3.88, p=0.0009$; female, $\left.t_{(16)}=3.44, p=0.003\right)$, whereas vehicle-infused groups did not perform significantly different from chance. These data illustrate that $\mathrm{DH}$ infusion of $\mathrm{E}_{2}$ enhances $\mathrm{OR}$ and spatial memory consolidation in both OVX females and gonadally-intact males.

\section{$E_{2}$ enhances memory consolidation in gonadally- intact and GDX males}

In males, the testes are the primary source of circulating androgens and estrogens, where estrogens are synthesized from testosterone by the enzyme aromatase. Both testosterone and $E_{2}$ regulate memory in males (Luine and Rodriguez, 1994; Vázquez-Pereyra et al., 1995; Packard et al., 1996; Gibbs, 2005; Kritzer et al., 2007; McConnell et al., 2012), so the presence of the testes in our study of gonadally-intact males may have influenced our findings in experiment 1. To address this possibility, sham GDX and GDX males were infused with vehicle or $E_{2}$ into the $\mathrm{DH}$ immediately after training in OP and OR (experiment 2). Two-way ANOVAs revealed significant main effects of $\mathrm{E}_{2}$ treatment for OP $\left(F_{(1,35)}=22.84, p<0.0001\right.$; Fig. $\left.2 A\right)$ and $\operatorname{OR}\left(F_{(1,32)}=9.72, p=0.0038\right.$; Fig. $\left.2 B\right)$. These data suggest that the loss of the testes does not prevent $\mathrm{DH} \mathrm{E}_{2}$ from enhancing memory, and indicates that $E_{2}$ can enhance memory in males regardless of the presence of testicular hormones. One-sample $t$ tests confirmed that both $\mathrm{E}_{2}$-treated groups spent significantly more time with the moved and novel objects than chance (sham $+E_{2}$, OP:
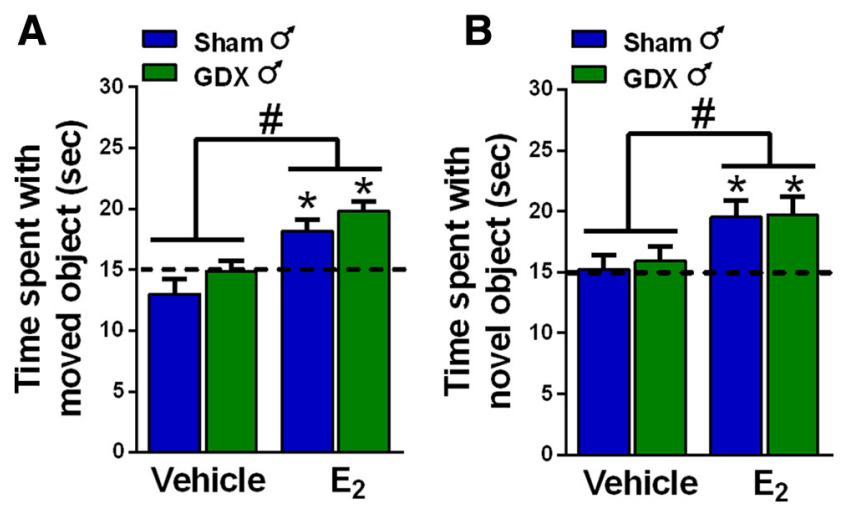

Figure 2. Infusion of $\mathrm{E}_{2}$ into the $\mathrm{DH}$ enhanced spatial and $\mathrm{OR}$ memory consolidation in both intact and GDX males. $E_{2}$-treated mice explored the moved $(\boldsymbol{A})$ or novel $(\boldsymbol{B})$ object in the OP and OR tasks significantly more than chance $(* p<0.05)$. Both $E_{2}$-treated male groups also spent significantly more time with the moved or novel object than vehicle-treated controls (\#p < 0.05). Each bar represents the mean +/- SEM.

$t_{(7)}=3.43, p=0.01$, OR: $t_{(8)}=3.37, p=0.01 ; \mathrm{GDX}+\mathrm{E}_{2}$, OP: $t_{(10)}=6.15, p=0.0001$, OR: $t_{(7)}=3.28, p=0.01$ ), whereas the vehicle-treated groups did not. Together, these analyses demonstrate that $\mathrm{E}_{2}$ enhances $\mathrm{OR}$ and spatial memory consolidation similarly in gonadally-intact and GDX male mice.

\section{$E_{2}$ does not increase DH ERK or Akt}

\section{phosphorylation in gonadally-intact males}

$\mathrm{DH} \mathrm{E}_{2}$ infusion significantly increases phosphorylation of the p42 isoform of ERK (p42-ERK) in the DH of OVX mice within 5 min (Fernandez et al., 2008; Fan et al., 2010; Boulware et al., 2013; Fortress et al., 2013; Kim et al., 2016). Moreover, ERK phosphorylation in the $\mathrm{DH}$ is required for $E_{2}$ to enhance memory consolidation in $O R$ and $\mathrm{OP}$, as demonstrated by studies in which $\mathrm{DH}$ infusion of the ERK phosphorylation inhibitor U0126 prevented intracerebroventricularly-infused $\mathrm{E}_{2}$ from facilitating memory consolidation in OVX mice (Fernandez et al., 2008; Fortress et al., 2013). To determine whether similar underlying mechanisms are responsible for $E_{2}$-induced memory consolidation in males, $\mathrm{DH}$ homogenates were obtained from the OVX females and sham GDX males in which $E_{2}$ enhanced memory consolidation (experiment 1). Two weeks after the completion of behavioral testing, mice received bilateral $\mathrm{DH}$ infusions of vehicle or $\mathrm{E}_{2}$, and dorsal hippocampi were bilaterally dissected 5 min later. Phospho-p42 ERK levels were significantly increased in OVX females, but not in intact males (Fig. $3 A$ ), as shown by a significant sex $\times$ treatment interaction $\left(F_{(1,59)}=5.11\right.$, $p=0.028)$, as well as main effects of treatment $\left(F_{(1,59)}=\right.$ $4.57, p=0.037)$ and $\operatorname{sex}\left(F_{(1,59)}=5.11, p=0.028\right)$. Post hoc analyses revealed that $E_{2}$-treated females had elevated phospho-p42 ERK levels relative to vehicle-treated females $(p=0.027)$ and $E_{2}$-treated males $(p=0.0013)$, whereas phosho-p42 ERK levels did not differ between the male groups. As in our previous studies with OVX females (Fernandez et al., 2008; Zhao et al., 2010; Boulware et al., 2013; Fortress et al., 2013; Kim et al., 2016), $E_{2}$ 

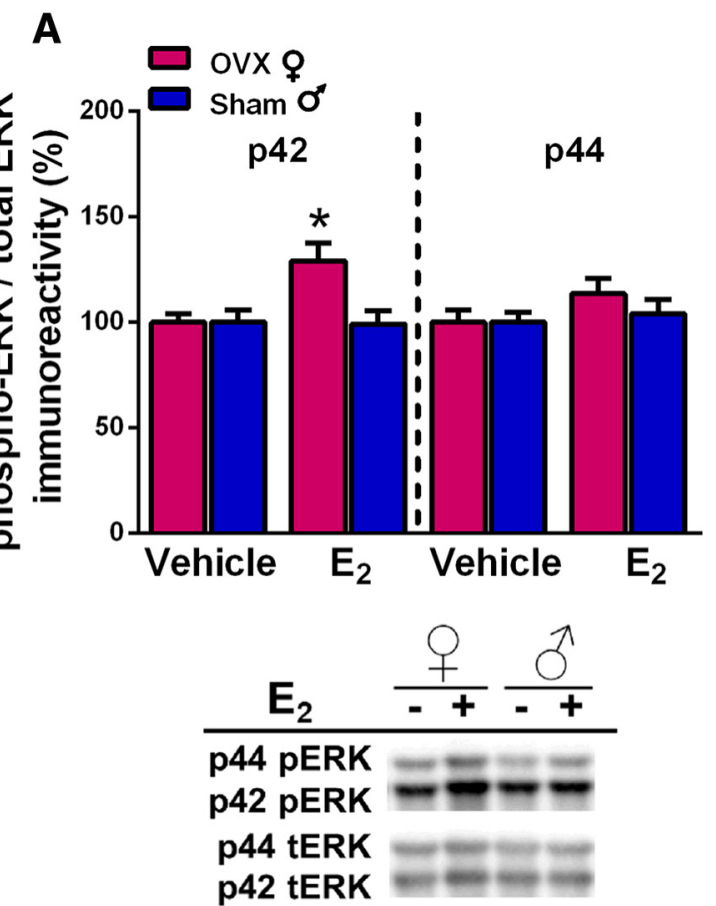

B
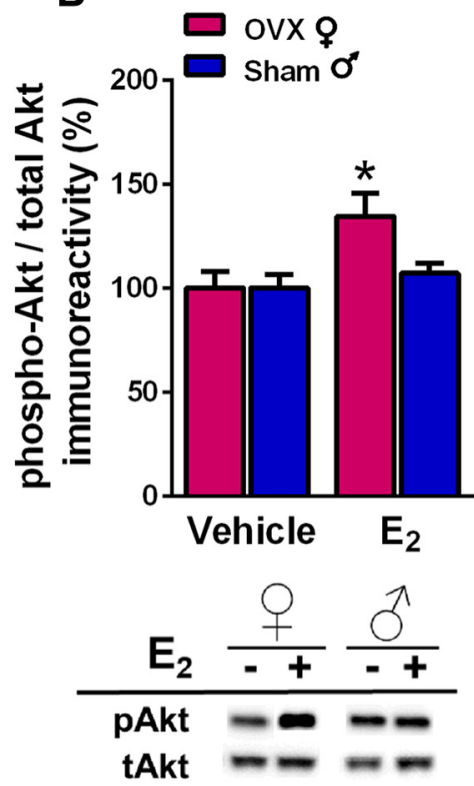

Figure 3. $\mathrm{DH} \mathrm{E}_{2}$ infusion significantly increased phosphorylation of the p42 isoform of ERK $(\boldsymbol{A})$ and of $A k t(\boldsymbol{B})$ in the DH of OVX females, but not sham GDX males. $\boldsymbol{A}$, Levels of phospho-p42, but not phospho-p44, ERK were significantly increased by $E_{2}$ in OVX females but not sham males. $\boldsymbol{B}, \mathrm{E}_{2}$ also significantly increased $\mathrm{DH}$ phospho-Akt levels in females but not males. Representative blots are shown below both graphs; $* p<0.05$ relative to the same-sex vehicle-infused group. Each bar represents the mean $+/-\mathrm{SEM}$.

had no significant effect on the phosphorylation of the p44 isoform of ERK in either sex.

Given that ERK phosphorylation was not increased in sham GDX males, we sought converging evidence from an upstream signaling pathway known to activate ERK. Akt is part of the phosphoinositol 3-kinase (PI3K)/Akt signaling pathway. Our previous work in OVX females showed that $\mathrm{E}_{2}$ increased phosphorylation of both PI3K and Akt within 5 min of DH infusion, and that activation of PI3K was necessary for $E_{2}$ to increase both p42 ERK phosphorylation and OR memory consolidation (Fan et al., 2010; Fortress et al., 2013). Thus, we used phosphorylated Akt as an indicator of whether $E_{2}$ activated the $\mathrm{PI}$ KK/Akt pathway in a subset of the OVX female and sham GDX male samples examined above. Two-way ANOVA indicated a significant main effect of $E_{2}$ treatment $\left(F_{(1,39)}=14.4, p=0.0096 ;\right.$ Fig. $\left.3 B\right)$ and trends for a main effect of $\operatorname{sex}\left(F_{(1,39)}=6.32, p=0.079\right)$ and sex $\times$ treatment interaction $\left(F_{(1,39)}=6.32, p=0.079\right)$. Post hoc tests revealed that $E_{2}$-treated females had elevated phosphoAkt levels relative vehicle-treated females $(p=0.0044)$ and $E_{2}$-treated males $(p=0.0162)$, whereas phospho-Akt levels did not differ significantly between the male groups. These data provide additional evidence that ERK and upstream signaling kinases in the $\mathrm{DH}$ are not necessary for $E_{2}$ to enhance memory in sham GDX males.

\section{ERK phosphorylation is not necessary for $E_{2}$ to enhance memory in GDX or gonadally-intact males}

Although the lack of ERK and Akt activation in sham GDX males suggests that $\mathrm{DH} \mathrm{E}_{2}$ infusion does not activate these pathways within $5 \mathrm{~min}$, it remains possible that these signaling kinases are affected at later time points where they could facilitate memory consolidation. In OVX mice, our laboratory has shown that bilateral $\mathrm{DH}$ infusion of a behaviorally subeffective dose of the ERK phosphorylation inhibitor U0126 $(0.5 \mu \mathrm{g} / \mathrm{hemisphere})$ prevents intracerebroventricularly-infused $E_{2}$ from enhancing OP and OR memory consolidation (Fernandez et al., 2008; Fortress et al., 2013). Here, the identical experiment was performed in GDX and sham GDX males to more definitively assess the role of ERK activation in the memoryenhancing effects of $E_{2}$ in males.

Before performing this study, it was first necessary to identify a dose of U0126 that did not affect memory on its own in males (experiment 3). This step was important to ensure that any memory-impairing effects of $E_{2}$ and U0126 given in combination were not due to a general memory-impairing effect of U0126 (Fernandez et al., 2008). In OVX females, bilateral DH infusion of $1 \mu \mathrm{g} /$ hemisphere U0126 impairs OP and OR memory consolidation, whereas 0.5 and $0.1 \mu \mathrm{g} /$ hemisphere do not (Fernandez et al., 2008; Boulware et al., 2013). In the present study, GDX males were bilaterally infused with vehicle or U0126 in doses of $0.25,0.5$, or $1 \mu \mathrm{g} / \mathrm{hemi-}$ sphere. One-way ANOVAs revealed significant main effects of $E_{2}$ treatment for $\mathrm{OP}\left(F_{(3,27)}=5.12, p=0.006\right.$; Fig. $4 A)$ and OR $\left(F_{(3,30)}=4.29, p=0.012\right.$; Fig. $\left.4 B\right)$. Post hoc analyses indicated that the group who received $1 \mu \mathrm{g} /$ hemisphere of U0126 performed worse than all other groups in both tasks $(p<0.02)$. One-sample $t$ tests for OP showed that all groups but the $1-\mu \mathrm{g}$ group spent significantly more time than chance with the moved object (vehicle, $t_{(9)}=2.34, p=0.04 ; 0.25 \mu \mathrm{g}, t_{(5)}=3.14, p=$ 

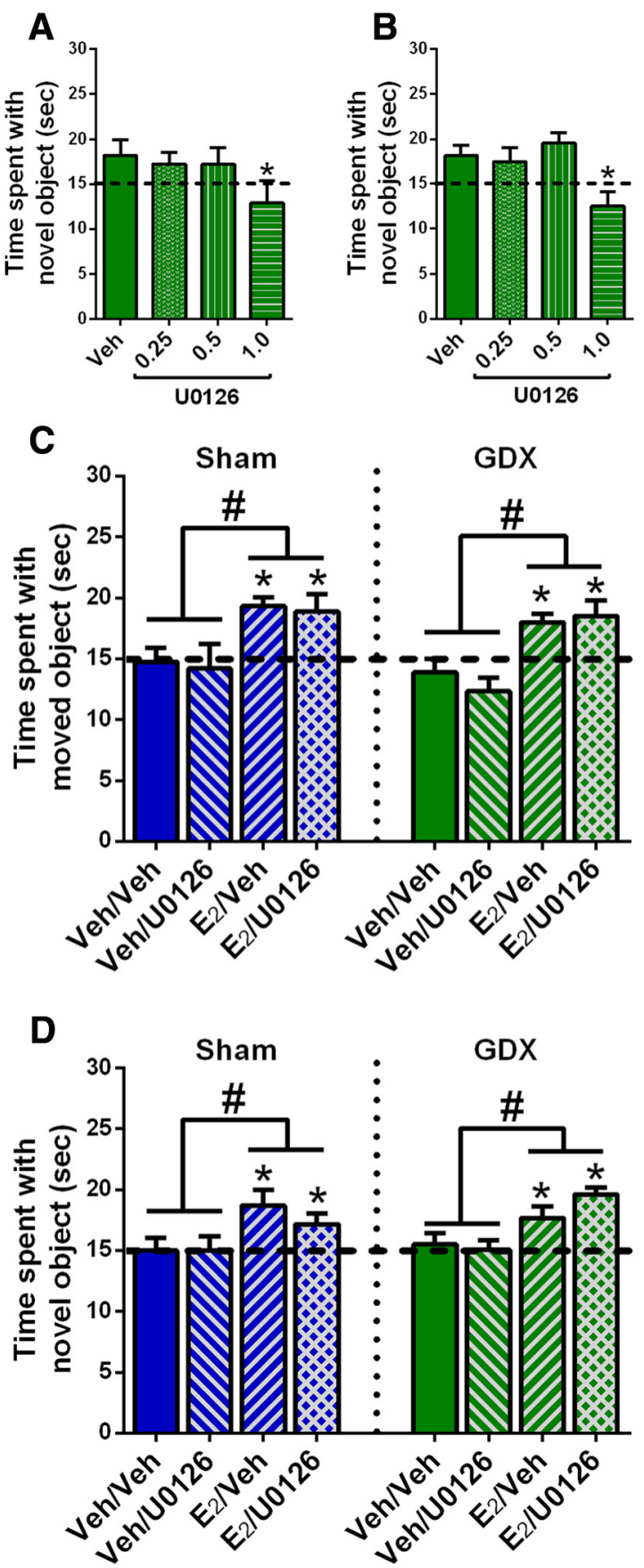

Figure 4. The ERK phosphorylation inhibitor U0126 did not block the memory-enhancing effects of $\mathrm{E}_{2}$ in intact or GDX males. $\boldsymbol{A}, \boldsymbol{B}$, Three doses of U0126 were tested to find one that did not impair memory consolidation on its own. In both OP $(\boldsymbol{A})$ and OR $(\boldsymbol{B}), 1.0$ $\mu \mathrm{g} / \mathrm{h}$ emisphere U0126 impaired memory consolidation, whereas $0.5 \mu \mathrm{g} /$ hemisphere U0126 did not. As such, $0.5 \mu \mathrm{g} /$ hemisphere U0126 was next co-infused with $E_{2}$ to determine whether the beneficial effects of $E_{2}$ on memory in males depended on ERK phosphorylation. $\boldsymbol{C}, \boldsymbol{D}$, Sham and GDX male mice receiving intracerebroventricular infusion of $E_{2}$ spent significantly more time than chance $(* p<0.05$; dashed line) exploring the moved or novel object in OP $(\boldsymbol{C})$ and OR $(\boldsymbol{D})$, regardless of whether they received a $\mathrm{DH}$ infusion of vehicle (Veh) or U0126. In contrast, mice receiving intracerebroventricular vehicle and $\mathrm{DH}$ vehicle or U0126 did not differ from chance in time spent with the moved

\section{Figure 4. continued}

and novel objects. Time spent with the novel and moved objects in the $E_{2}$-infused groups was significantly higher than that in the vehicle groups, independent of U0126 administration (\#p < 0.05). Each bar represents the mean +/- SEM.

$0.03 ; 0.5 \mu \mathrm{g}, t_{(6)}=6.41, p=0.0007 ; 1 \mu \mathrm{g}, t_{(7)}=1.18, p=$ $0.27)$. For $\mathrm{OR}$, one-sample $t$ tests showed that groups infused with vehicle $\left(t_{(9)}=2.66, p=0.03\right)$ or $0.5 \mu \mathrm{g}\left(t_{(7)}=\right.$ 3.86, $p=0.006$ ) spent significantly more time than chance with the novel object, whereas the $0.25-\mu \mathrm{g}\left(t_{(8)}=\right.$ $1.61, p=0.15)$ and $1-\mu \mathrm{g}\left(t_{(6)}=1.57, p=0.17\right)$ groups did not. It is unclear why the $0.25-\mu \mathrm{g}$ group would not have shown stronger evidence of learning in OR. Nevertheless, the data suggests that the $0.5 \mu \mathrm{g} /$ hemisphere dose of U0126 does not affect OP or OR memory consolidation. These results are consistent with our previous findings from OVX mice in which $1.0 \mu \mathrm{g}$, but not $0.5 \mu \mathrm{g}$, impaired OR and OP memory consolidation (Fernandez et al., 2008; Boulware et al., 2013). Because $0.5 \mu \mathrm{g}$ was also the highest non-impairing dose of U0126 in the present study, we used the $0.5-\mu \mathrm{g}$ dose in subsequent experiments to examine the role of ERK phosphorylation in the memoryenhancing effects of $E_{2}$ in sham GDX and GDX males.

Next, sham GDX males were infused with vehicle or 0.5 $\mu \mathrm{g} /$ hemisphere U0126 into the $\mathrm{DH}$ and vehicle or $10 \mu \mathrm{g} \mathrm{E}_{2}$ into the dorsal third ventricle immediately after $\mathrm{OR}$ and $\mathrm{OP}$ training (experiment $4 \mathrm{a}$ ). $\mathrm{DH}$ infusions occurred immediately before intracerebroventricular infusions. The infusion of $10 \mu \mathrm{g} \mathrm{E}_{2}$ intracerebroventricular (same total dose as the two bilateral $5-\mu \mathrm{g}$ infusions) delivers $\mathrm{E}_{2}$ adjacent to the $\mathrm{DH}$ while preventing potential tissue damage to the $\mathrm{DH}$ from multiple infusions of $E_{2}$ and $U 0126$ in rapid succession (Fortress et al., 2015; Kim et al., 2016). DH-infused U0126 did not prevent intracerebroventricularly-infused $E_{2}$ from enhancing memory consolidation in either task, as indicated by significant main effects of $E_{2}$ treatment for OP $\left(F_{(1,20)}=10.91, p=0.0036\right.$; Fig. $\left.4 C\right)$ and OR $\left(F_{(1,31)}=\right.$ $6.91, p=0.0132$; Fig. $4 D$ ) in the absence of significant main effects for U0126 treatment or $E_{2} \times$ U0126 interactions. In support of these findings, one-sample $t$ tests showed that groups infused with $\mathrm{E}_{2}+$ vehicle $\left(\mathrm{OP}, t_{6}\right)$ 5.93, $p=0.001$; OR, $\left.t_{(8)}=2.91, p=0.02\right)$ or $\mathrm{E}_{2}+\mathrm{U} 0126$ $\left(\mathrm{OP}, t_{(6)}=2.7, p=0.036\right.$; OR, $t_{(9)}=2.37, p=0.04$ ) spent significantly more time with the moved and novel objects, whereas groups infused with vehicle + vehicle or vehicle + U0126 did not. Similar effects were found in GDX males (experiment $4 b$ ). Two-way ANOVAs revealed significant main effects of $E_{2}$ treatment in OP $\left(F_{(1,27)}=20.76, p=\right.$ 0.0001 ; Fig. $4 C)$ and $\mathrm{OR}\left(F_{(1.35)}=13.3, p=0.0009\right.$; Fig. $4 D$ ), in the absence of main effects for U0126 treatment or significant interactions. Also consistent with this finding, one-sample $t$ tests revealed that GDX males treated with $E_{2}+$ vehicle or $E_{2}+$ U0126 spent significantly more time with the moved object than chance in OP $\left(E_{2}+\right.$ vehicle: $t_{(7)}$ $=4.35, p=0.033 ; \mathrm{E}_{2}+$ U0126: $\left.t_{(8)}=2.61, p=0.03\right)$ and with the novel object than chance in OR $\left(\mathrm{E}_{2}+\right.$ vehicle: $t_{(10)}$ $=2.8, p=0.02 ; \mathrm{E}_{2}+$ U0126: $\left.t_{(8)}=8.14, p=0.0001\right)$. In contrast, males treated with vehicle + vehicle or vehicle + U0126 performed at chance levels in both tasks. These 


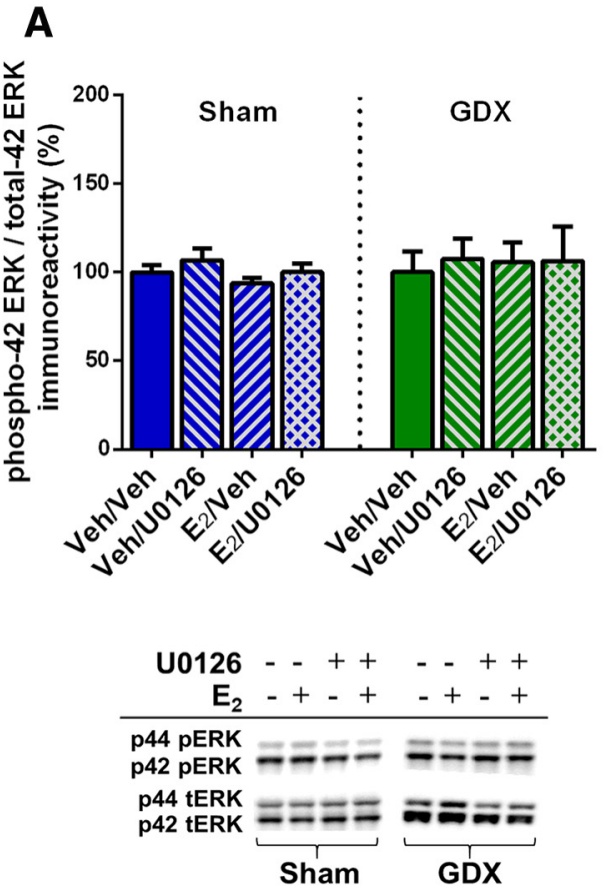

B
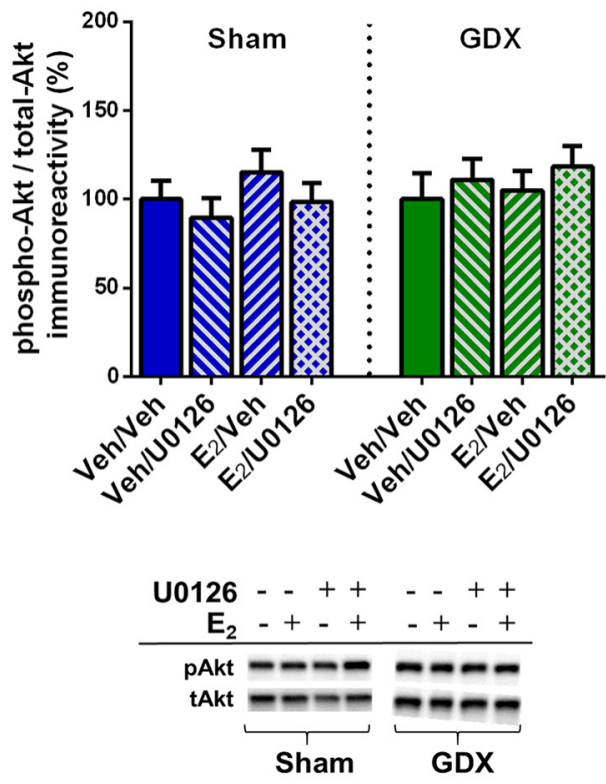

Figure 5. $\mathrm{E}_{2}$ did not increase phosphorylated ERK or Akt levels in sham or GDX males, independent of U0126 administration. All groups displayed similar levels of phospho-p42 ERK $(\boldsymbol{A})$ and phospho-Akt $(\boldsymbol{B})$ protein after intracerebroventricular infusion of vehicle or $\mathrm{E}_{2}$ and $\mathrm{DH}$ infusion of vehicle or U0126. Representative blots for each antibody are shown to below the quantified data. Each bar represents the mean $+/-$ SEM.

data suggest that ERK phosphorylation is not required for $E_{2-}$ to-enhance OR or spatial memory consolidation.

To verify that ERK and Akt phosphorylation were not affected by $E_{2}$ or $\mathrm{U} 0126$ in the aforementioned behaviorallytested sham GDX and GDX males, mice were infused two weeks after the conclusion of behavioral testing and $\mathrm{DH}$ tissue collected 5 min later. Two-way ANOVAs revealed no significant main effects or interaction between $E_{2}$ and U0126 treatment for phospho-p42 ERK, phospho-p44 ERK, or phospho-Akt in either sham GDX or GDX males (Fig. 5). These data confirm that $E_{2}$ does not increase DH ERK or Akt phosphorylation 5 min after DH infusion in either sham GDX or GDX males. As such, they replicate $E_{2}$ 's lack of effect on ERK and Akt in sham GDX males reported in experiment 1 and extend this finding to GDX males, suggesting that testicular hormones do not influence the effects of exogenous $\mathrm{E}_{2}$ on these signaling kinases.

Combined, these data demonstrate that ERK phosphorylation in the $\mathrm{DH}$ is not required for $\mathrm{E}_{2}$ to enhance object recognition and spatial memory consolidation in male mice. These findings are inconsistent with our previous studies in OVX mice in which the same dose of U0126 blocked the memory-enhancing effects of $E_{2}$ on object recognition and spatial memory consolidation (Fernandez et al., 2008; Fan et al., 2010; Fortress et al., 2013), suggesting potentially important sex differences in the signaling mechanisms through which $\mathrm{E}_{2}$ regulates memory consolidation.

\section{$E_{2}$ increases CREB phosphorylation in OVX females, gonadally-intact males, and GDX males}

Given the apparent sex differences in the role ERK phosphorylation in $\mathrm{E}_{2}$-induced memory enhancement, we decided to examine possible $E_{2}$ effects on the transcrip- tion factor CREB. ERK increases CREB phosphorylation (Adams and Sweatt, 2002), yet $E_{2}$ increases CREB phosphorylation in cultured female, but not male, hippocampi (Boulware et al., 2005). Due to the sex differences in $E_{2}$-induced ERK phosphorylation observed in our studies, we hypothesized that $E_{2}$ would increase CREB phosphorylation in females, but not males. Homogenates from mice in experiments 1 and 4 above were assayed for phosphoCREB levels. We first compared OVX females to intact males (experiment 1). Contrary to our hypothesis, $E_{2}$ increased DH CREB phosphorylation in both sexes (Fig. $6 A$ ), as suggested by a significant main effect of $E_{2}$ treatment $\left(F_{(1,20)}=5.06, p=0.04\right)$ in the absence of a significant main effect of sex or sex $\times E_{2}$ treatment interaction. This finding suggested that $E_{2}$ activates CREB in males in a manner independent of ERK phosphorylation. To further support this conclusion, we assayed CREB phosphorylation in homogenates from experiment 4 , in which sham GDX and GDX males infused with U0126 or vehicle (DH) and $E_{2}$ or vehicle (intracerebroventricular). Although a two-way ANOVA only reported a trend for an $E_{2}$ enhancement of phospho-CREB in sham mice $\left(F_{(1,18)}=3.46, p=\right.$ 0.079 ; Fig. $6 B$ ), there was a significant main effect of $E_{2}$ treatment in the GDX mice $\left(F_{(1,18)}=5.65, p=0.03\right.$; Fig. $6 B)$. Moreover, no main effects of U0126 treatment or $E_{2}$ $\times$ U0126 interactions were significant. Together, these data suggest that $E_{2}$ treatment may enhance memory in male mice through the phosphorylation of CREB in a manner independent from ERK or Akt signaling.

\section{Discussion}

The current study demonstrates a novel sex difference in the molecular mechanisms through which $E_{2}$ enhances 
A
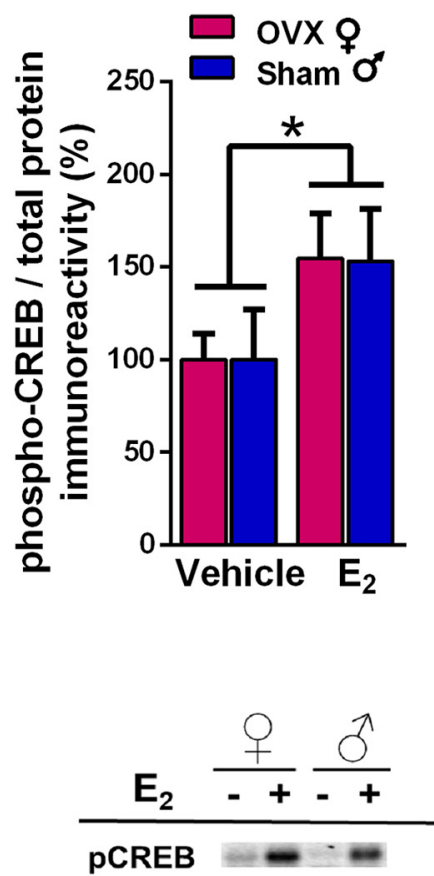

B
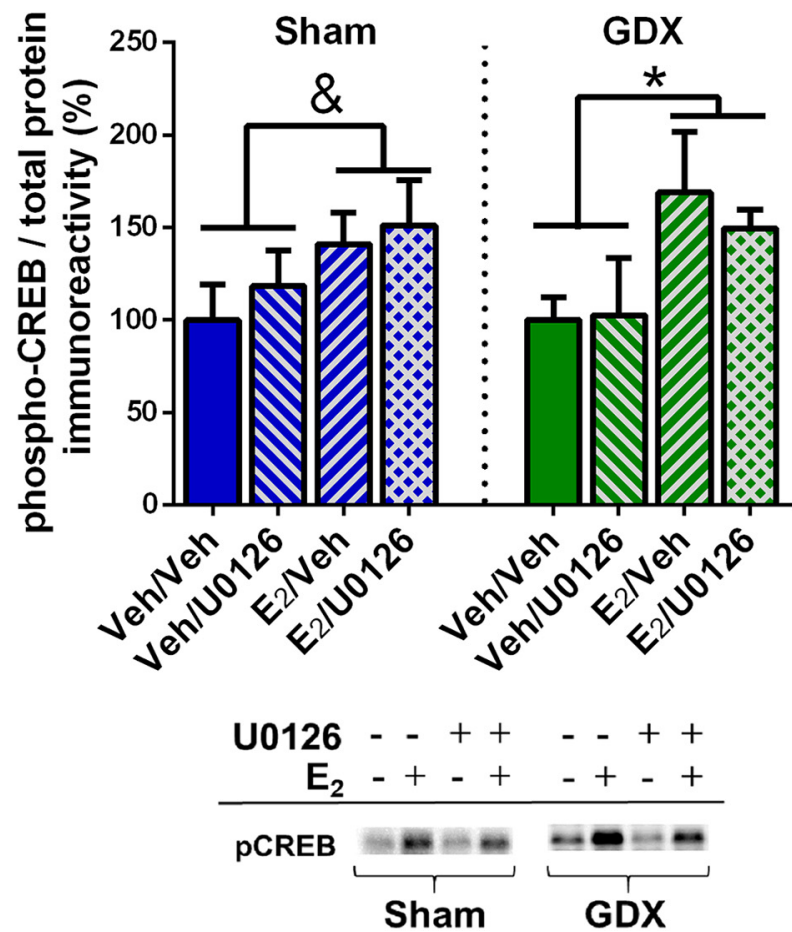

Figure 6. Effects of $\mathrm{E}_{2}$ on levels of phospho-CREB in the DH of OVX females, sham males, and GDX males. $\boldsymbol{A}$, DH infusion of $\mathrm{E}_{2}$ significantly increased levels of phospho-CREB in the DH of OVX females and sham males relative to same-sex vehicle-infused mice $(* p<0.05)$. B, In GDX males, $\mathrm{E}_{2}$ significantly increased phospho-CREB levels in the $\mathrm{DH}(* p<0.05)$, and administration of U0126 did not block this increase. In sham males, there was a trend for $E_{2}$ to increase phospho-CREB levels in the DH regardless of U0126 infusion $(\& p=0.079)$. Representative blots for each antibody are shown to below the quantified data. Each bar represents the mean $+/-$ SEM.

memory consolidation. In both sexes, $\mathrm{E}_{2}$ infused into the $\mathrm{DH}$ enhanced object recognition and spatial memory consolidation in the OR and OP tasks, but the cell-signaling mechanisms employed appear to differ. Our laboratory previously demonstrated that the ability of systemic or dorsal hippocampally-infused $E_{2}$ to enhance memory consolidation in OVX females depends on DH p42-ERK phosphorylation (Fernandez et al., 2008; Fan et al., 2010; Zhao et al., 2010; Fortress et al., 2013). Here, $E_{2}$ infusion did not increase p42-ERK phosphorylation in intact or GDX males, nor was ERK phosphorylation required for $E_{2}$ to enhance memory consolidation in males. Comparison of these data sets strongly suggests that $E_{2}$ regulates memory consolidation via different cell-signaling pathways in males and females, although the signaling mechanisms employed in males remain unclear. Interestingly, CREB phosphorylation was increased by $E_{2}$ in both sexes, and the increase in males was not dependent on ERK phosphorylation, suggesting the involvement of other signaling pathways that activate CREB.

This study is the first to show that acute $\mathrm{DH} \mathrm{E}_{2}$ infusion can enhance object recognition and spatial memory consolidation in gonadally-intact and GDX males. This finding is consistent with previous reports that chronic systemic $E_{2}$ facilitates memory formation among intact or GDX males tested in various spatial tasks (Luine and Rodriguez, 1994; Heikkinen et al., 2002; Gibbs, 2005; Locklear and Kritzer, 2014), and studies using acute or chronic $E_{2}$ in similar object-based tasks to those used here (McCo- nnell et al., 2012; Jacome et al., 2016). The present study is particularly unique in directly comparing effects of $E_{2}$ in males and females, as well as intact and GDX males, within the same study. Several studies report memory deficits after GDX (Ceccarelli et al., 2001; Kritzer et al., 2001, 2007; Daniel et al., 2003; Sandstrom et al., 2006; Aubele et al., 2008; Gibbs and Johnson, 2008; Spritzer et al., 2008; Locklear and Kritzer, 2014), some of which can be rescued by $\mathrm{E}_{2}$ administration (Luine and Rodriguez, 1994; Gibbs, 2005; Gibbs and Johnson, 2008). Although the particular testing delays used in the present study precluded assessment of GDX effects on memory consolidation, the data clearly show that the dorsal hippocampi of both GDX and intact males are responsive to exogenous $E_{2}$, independent of circulating androgens and estrogens. The male hippocampus can aromatize its own $E_{2}$ from androgen precursors (Fargo et al., 2009), so this responsiveness may result from sensitivity to de novo $\mathrm{E}_{2}$ synthesis within the $\mathrm{DH}$. This study did not directly test a potential role for hippocampal-synthesized $E_{2}$ in the mnemonic responses of males, but preliminary and published data from our lab suggest that aromatase inhibition in the DH blocks OR and OP memory consolidation in GDX female and male, but not intact male, mice (Tuscher et al., 2016b; Koss et al., 2018). Additional work will be necessary to ascertain the relative role of testicular and hippocampal $\mathrm{E}_{2}$ to memory consolidation in males. 
Although $E_{2}$ enhanced memory in males, the underlying molecular mechanisms appear to differ between the sexes. In OVX mice, $E_{2}$ enhances memory consolidation by sequentially activating PI3K/Akt, ERK, and mTOR signaling in the DH (Fernandez et al., 2008; Fan et al., 2010; Fortress et al., 2013). DH infusion of U0126 or an mTOR inhibitor not only prevents $E_{2}$ from enhancing memory (Fernandez et al., 2008; Fortress et al., 2013), but also from increasing CA1 dendritic spine density (Tuscher et al., 2016a) in OVX mice. As such, rapid ERK activation is essential for effects of $E_{2}$ on both memory consolidation and synaptic morphology in OVX females. In contrast, using the same methods and doses of $E_{2}$ and U0126, we report here that $E_{2}$ did not increase DH ERK phosphorylation, nor did inhibiting ERK activation block $\mathrm{E}_{2}$-induced memory consolidation, in intact or GDX males. Although the inability of U0126 to block the memory-enhancing effects of $E_{2}$ could be related to sex differences in interactions between $E_{2}$ and $U 0126$, this unlikely because: (1) our U0126 dose-response data are identical in males (this study) and females (Fernandez et al., 2008; Boulware et al., 2013), and (2) our Western blottings in males repeatedly showed no effect of $E_{2}$ on ERK or Akt phosphorylation in males. Together, our previous findings and the present study indicate that the cell-signaling mechanisms underlying the memory-enhancing effects of $\mathrm{DH}$-infused $\mathrm{E}_{2}$ differ between the sexes.

The molecular basis for the discrepant roles of ERK in memory consolidation among females and males may lie in sex differences in estrogen receptor (ER) distribution or function. Although overall hippocampal $\mathrm{ER} \alpha$ and $\mathrm{ER} \beta$ distribution is similar in males and females (Romeo et al., 2005; Mitterling et al., 2010), differences in subcellular ER localization could contribute to the sex differences in cell signaling shown here. For example, $\mathrm{E}_{2}$ potentiates hippocampal glutamateric synaptic transmission via different ER mechanisms in GDX male and female rats; glutamate release probability is regulated presynaptically by $\operatorname{ER} \beta$ in females and $E R \alpha$ in males, whereas glutamate sensitivity is mediated postsynaptically by GPER in females and ER $\beta$ in males (Oberlander and Woolley, 2016, 2017). Interestingly, GPER activation in the DH does not phosphorylate ERK or depend on ERK activation to enhance OR and OP memory consolidation in OVX female mice; rather it enhances memory by activating c-Jun $\mathrm{N}$-terminal kinase (JNK; Kim et al., 2016). Thus, sex differences in ER distribution could lead to ERK-independent signaling in males mediated by GPER or other receptors, like glutamatergic receptors. In OVX female mice, metabotropic (mGluR1a) and ionotropic (NMDA) glutamate receptors are necessary for $E_{2}$ to activate ERK and enhance OR and OP memory consolidation (Lewis et al., 2008; Boulware et al., 2013). ER $\alpha$ and $E R \beta$ enhance OR and OP memory consolidation in OVX females by interacting with mGluR1a at the membrane to, most likely, potentiate the G-protein signaling that occurs as mGluR1a is bound by glutamate (Boulware et al., 2013). Additionally, $\mathrm{E}_{2}$ increases NMDA neurotransmission in female rats by recruiting existing NMDA receptors to synaptic sites (Jelks et al., 2007; Snyder et al., 2011), although it is unknown whether $E_{2}$ affects glutamate receptors similarly in males. $E_{2}$ increases long-term potentiation (LTP) amplitude and reduces LTP threshold in both males and females (Smith and McMahon, 2006; Kramár et al., 2009; Smejkalova and Woolley, 2010; Tanaka and Sokabe, 2013; Kumar et al., 2015), but these effects depend on NMDA receptors in females and AMPA receptors in males (Smith and McMahon, 2006; Kramár et al., 2009). Thus, sex differences in interactions between $E_{2}$ and glutamate receptors could lead to differential cell signaling in males and females.

The activation of CREB in the $\mathrm{DH}$ by $\mathrm{E}_{2}$ in both sexes is consistent with work in male and female mice showing a similar phosphorylation of CREB in the $\mathrm{DH}$ by $\mathrm{E}_{2}$ (Abrahám and Herbison, 2005). However, that same study reported sex differences in $\mathrm{E}_{2}$-induced CREB activation among hypothalamic and basal forebrain nuclei. Another study using neonatal cultured hippocampal neurons from male and female rats demonstrated that $E_{2}$ activated ERK, CREB, and CRE-mediated gene transcription in females but not males (Boulware et al., 2005). These inconsistencies may be due to differences in species, in vitro versus in vivo methodologies, or hippocampal subregion specificity. For example, our lab demonstrated that contextual fear conditioning induced greater p42 ERK phosphorylation in the ventral, but not dorsal, hippocampus in male rats relative to females (Gresack et al., 2009). However, the present study and that by Abrahám and Herbison (2005) both report that $E_{2}$ increases CREB phosphorylation in vivo in the $\mathrm{DH}$ of adult male and female mice, suggesting some degree of consistency in this finding.

CREB phosphorylation is important for hippocampal dendritic spinogenesis, synaptic plasticity, and memory consolidation (Murphy and Segal, 1997; Lonze and Ginty, 2002; Alberini, 2009; Kida, 2012). CREB can be activated through multiple independent cell-signaling pathways including ERK, protein kinases $A$ and $C$ (PKA, PKC), multiple calcium/calmodulin kinases (CaMKs), and p38 MAPK (Lonze and Ginty, 2002). Our data from both sham and GDX males suggest that ERK activation is not necessary for $E_{2}$ to increase pCREB levels in the $\mathrm{DH}$. It is unclear if the same is true for females because our previous studies of $E_{2}$ and U0126 infusion in OVX mice did not measure pCREB levels; however, we doubt this because $E_{2}$ induced alterations in memory consolidation, epigenetic processes, and local protein translation depend on ERK phosphorylation in OVX mice (Zhao et al., 2010; Fortress et al., 2013). Among males, other kinases could mediate the effects of $E_{2}$ on memory and CREB, given the multitude of other signaling molecules that regulate CREB phosphorylation. In studies using cultured embryonic hippocampal neurons, in which sex was not reported, $E_{2}$ increased CREB phosphorylation in a manner dependent on $\mathrm{Ca}^{2+}$, NMDA receptors, ERK, PKA, and CaMKII (Murphy and Segal, 1997; Zhao et al., 2005; O'Neill et al., 2008), suggesting perhaps a role for p38 MAPKs or PKC. However, in other embryonic hippocampal cultures, the potent androgen dihydrotestosterone activates CREB through PKC without activation of ERK, CaMKIV, or PKA (Nguyen et al., 2009). Thus, it is possible for hormones to regulate CREB via some kinases and not others. Given 
the lack of in vivo data on this subject, more research in both sexes is clearly needed to parse the mechanisms underlying the memory-enhancing effects of $E_{2}$.

The current study demonstrates novel sex differences in the cell-signaling mechanisms through which $\mathrm{E}_{2}$ regulates memory consolidation. The present data are consistent with previous studies showing that $E_{2}$ can enhance memory consolidation in both males and females. However, whereas ERK signaling is necessary for this effect in females, it plays no role in GDX or intact males. Sex differences in molecular means to the same phenotypic end could greatly influence the development of treatments to reduce memory dysfunction conditions such as drug addiction, Alzheimer's disease, and developmental disorders which differ in severity or risk between the sexes. Sex differences in function at the subcellular level may provide insight into the nature of sex differences in these conditions and lead to more effective, possibly sex-specific, treatments for neuropsychiatric and neurodegenerative diseases.

\section{References}

Abrahám IM, Herbison AE (2005) Major sex differences in nongenomic estrogen actions on intracellular signaling in mouse brain in vivo. Neuroscience 131:945-951. CrossRef Medline

Adams JP, Sweatt JD (2002) Molecular psychology: roles for the ERK MAP kinase cascade in memory. Annu Rev Pharmacol Toxicol 42:135-163. CrossRef Medline

Alberini CM (2009) Transcription factors in long-term memory and synaptic plasticity. Physiol Rev 89:121-145. CrossRef Medline

Aubele T, Kaufman R, Montalmant F, Kritzer MF (2008) Effects of gonadectomy and hormone replacement on a spontaneous novel object recognition task in adult male rats. Horm Behav 54:244252. CrossRef Medline

Baker KB, Kim JJ (2002) Effects of stress and hippocampal NMDA receptor antagonism on recognition memory in rats. Learn Mem 9:58-65. CrossRef Medline

Boulware MI, Weick JP, Becklund BR, Kuo SP, Groth RD, Mermelstein PG (2005) Estradiol activates group I and II metabotropic glutamate receptor signaling, leading to opposing influences on cAMP response element-binding protein. J Neurosci 25:50665078. CrossRef

Boulware MI, Heisler JD, Frick KM (2013) The memory-enhancing effects of hippocampal estrogen receptor activation involve metabotropic glutamate receptor signaling. J Neurosci 33:1518415194. CrossRef Medline

Ceccarelli I, Scaramuzzino A, Aloisi AM (2001) Effects of gonadal hormones and persistent pain on non-spatial working memory in male and female rats. Behav Brain Res 123:65-76. Medline

Cohen SJ, Munchow AH, Rios LM, Zhang G, Asgeirsdóttir HN, Stackman RW Jr (2013) The rodent hippocampus is essential for nonspatial object memory. Curr Biol 23:1685-1690. CrossRef Medline

Daniel JM, Winsauer PJ, Moerschbaecher JM (2003) Castration in rats impairs performance during acquisition of a working memory task and exacerbates deficits in working memory produced by scopolamine and mecamylamine. Psychopharmacology 170:294300. CrossRef Medline

Fan L, Zhao Z, Orr PT, Chambers CH, Lewis MC, Frick KM (2010) Estradiol-induced object memory consolidation in middle-aged female mice requires dorsal hippocampal extracellular signalregulated kinase and phosphatidylinositol 3-kinase activation. J Neurosci 30:4390-4400. CrossRef Medline

Fargo KN, Pak TR, Foecking EM, Jones KJ (2009) Molecular biology of androgen action. In: Molecular mechanisms of hormone actions on behavior (Etgen AM, Pfaff DW, eds), pp 127-152. San Diego, CA: Elsevier Inc.
Fernandez SM, Lewis MC, Pechenino AS, Harburger LL, Orr PT, Gresack JE, Schafe GE, Frick KM (2008) Estradiol-induced enhancement of object memory consolidation involves hippocampal extracellular signal-regulated kinase activation and membranebound estrogen receptors. J Neurosci 28:8660-8667. CrossRef Medline

Fortress AM, Fan L, Orr PT, Zhao Z, Frick KM (2013) Estradiolinduced object recognition memory consolidation is dependent on activation on mTOR signaling in the dorsal hippocampus. Learn Mem 20:147-155. CrossRef Medline

Fortress AM, Kim J, Poole RL, Gould TJ, Frick KM (2014) $17 \beta$ Estradiol regulates histone alterations associated with memory consolidation and increases Bdnf promoter acetylation in middleaged female mice. Learn Mem 21:457-467. CrossRef

Fortress AM, Heisler JD, Frick KM (2015) The mTOR and canonical Wnt signaling pathways mediate the mnemonic effects of progesterone in the dorsal hippocampus. Hippocampus 25:616-629. CrossRef Medline

Frick KM (2015) Molecular mechanisms underlying the memoryenhancing effects of estradiol. Horm Behav 74:4-18. CrossRef Medline

Frick KM, Gresack JE (2003) Sex differences in the behavioral response to spatial and object novelty in adult C57BL/6 mice. Behav Neurosci 117:1283-1291. CrossRef Medline

Frick KM, Kim J, Tuscher JJ, Fortress AM (2015) Sex steroid hormones matter for learning and memory: estrogenic regulation of hippocampal function in male and female rodents. Learn Mem 22:472-493. CrossRef Medline

Frick KM, Tuscher JJ, Koss WA, Kim J, Taxier LR (2018) Estrogenic regulation of memory consolidation: a look beyond the hippocampus, ovaries, and females. Physiol Behav 187:57-66. CrossRef Medline

Galea LAM, Frick KM, Hampson E, Sohrabji F, Choleris E (2017) Why estrogens matter for behavior and brain health. Neurosci Biobehav Rev 76:363-379. CrossRef Medline

Gibbs RB (2005) Testosterone and estradiol produce different effects on cognitive performance in male rats. Horm Behav 48:268-277. CrossRef Medline

Gibbs RB, Johnson DA (2008) Sex-specific effects of gonadectomy and hormone treatment on acquisition of a 12-arm radial maze task by Sprague Dawley rats. Endocrinology 149:3176-3183. CrossRef Medline

Gillies GE, McArthur S (2010) Estrogen actions in the brain and the basis for differential action in men and women: a case for sexspecific medicines. Pharmacol Rev 62:155-198. CrossRef Medline

Gresack JE, Schafe GE, Frick KM (2009) Sex differences in contextual fear conditioning are associated with differential ventral hippocampal extracellular signal-regulated kinase activation. Neuroscience 159:451-467. CrossRef Medline

Heikkinen T, Puoliväli J, Liu L, Rissanen A, Tanila H (2002) Effects of ovariectomy and estrogen treatment on learning and hippocampal neurotransmitters in mice. Horm Behav 41:22-32. CrossRef Medline

Inagaki T, Gautreaux C, Luine V (2010) Acute estrogen treatment facilitates recognition memory consolidation and alters monoamine levels in memory-related brain areas. Horm Behav 58:415426. CrossRef Medline

Jacome LF, Barateli K, Buitrago D, Lema F, Frankfurt M, Luine VN (2016) Gonadal hormones rapidly enhance spatial memory and increase hippocampal spine density in male rats. Endocrinology 157:1357-1362. CrossRef Medline

Jelks KB, Wylie R, Floyd CL, McAllister AK, Wise P (2007) Estradiol targets synaptic proteins to induce glutamatergic synapse formation in cultured hippocampal neurons: critical role of estrogen receptor- $\alpha$. J Neurosci 27:6903-6913. CrossRef

Kida S (2012) A functional role for CREB as a positive regulator of memory formation and LTP. Exp Neurobiol 21:136-140. CrossRef Medline

Kim J, Szinte JS, Boulware MI, Frick KM (2016) $17 \beta$-estradiol and agonism of G-protein coupled estrogen receptor enhance hippocampal memory via different cell-signaling mechanisms. J Neurosci 36:3309-3321. CrossRef Medline 
Kim J, Frick KM (2017) Distinct effects of estrogen receptor antagonism on object recognition and spatial memory consolidation in ovariectomized mice. Psychoneuroendocrinology 85:110-114. CrossRef Medline

Koss WA, Alf RL, Tuscher JJ, Frick KM (2018) The role of androgen receptors and hippocampal estradiol synthesis in memory consolidation in male mice. Soc Neurosci Abstract Poster 314.04

Kramár EA, Chen LY, Brandon NJ, Rex CS, Liu F, Gall CM, Lynch G (2009) Cytoskeletal changes underlie estrogen's acute effects on synaptic transmission and plasticity. J Neurosci 29:12982-12993. CrossRef

Kritzer MF, McLaughlin PJ, Smirlis T, Robinson JK (2001) Gonadectomy impairs T-maze acquisition in adult male rats. Horm Behav 39:167-174. CrossRef Medline

Kritzer MF, Brewer A, Montalmant F, Davenport M, Robinson JK (2007) Effects of gonadectomy on performance in operant tasks measuring prefrontal cortical function in adult male rats. Horm Behav 51:183-194. CrossRef Medline

Kumar A, Bean LA, Rani A, Jackson T, Foster TC (2015) Contribution of estrogen receptor subtypes, $\mathrm{ER} \alpha, \mathrm{ER} \beta$, and GPER1 in rapid estradiol-mediated enhancement of hippocampal synaptic transmission in mice. Hippocampus 25:1556-1566. CrossRef Medline

Lewis MC, Kerr KM, Orr PT, Frick KM (2008) Estradiol-induced enhancement of object memory consolidation involves NMDA receptors and protein kinase $A$ in the dorsal hippocampus of female C57BL/6 mice. Behav Neurosci 122:716-721. CrossRef Medline

Locklear MN, Kritzer MF (2014) Assessment of the effects of sex and sex hormones on spatial cognition in adult rats using the Barnes maze. Horm Behav 66:298-308. CrossRef Medline

Lonze BE, Ginty DD (2002) Function and regulation of CREB family transcription factors in the nervous system. Neuron 35:605-623. Medline

Luine V, Rodriguez M (1994) Effects of estradiol on radial arm maze performance of young and aged rats. Behav Neural Biol 62:230236. Medline

McConnell SE, Alla J, Wheat E, Romeo RD, McEwen B, Thornton JE (2012) The role of testicular hormones and luteinizing hormone in spatial memory in adult male rats. Horm Behav 61:479-486. CrossRef Medline

Milner TA, McEwen BS, Hayashi S, Li CJ, Reagan LP, Alves SE (2001) Ultrastructural evidence that hippocampal alpha estrogen receptors are located at extranuclear sites. J Comp Neur 429:355371. CrossRef

Milner TA, Ayoola K, Drake CT, Herrick SP, Tabori NE, McEwen BS, Warrier S, Alves SE (2005) Ultrastructural localization of estrogen receptor beta immunoreactivity in the rat hippocampal formation. J Comp Neur 491:81-95. CrossRef Medline

Mitterling KL, Spencer JL, Dziedzic N, Shenoy S, McCarthy K, Waters EM, McEwen BS, Milner TA (2010) Cellular and subcellular localization of estrogen and progestin receptor immunoreactivities in the mouse hippocampus. J Comp Neur 518:2729-2743. CrossRef Medline

Mukai H, Tsurugizawa T, Murakami G, Kominami S, Ishii H, OgiueIkeda M, Takata N, Tanabe N, Furukawa A, Hojo Y, Ooishi Y, Morrison JH, Janssen WG, Rose JA, Chambon P, Kato S, Izumi S, Yamazaki T, Kimoto T, Kawato S (2007) Rapid modulation of long-term depression and spinogenesis via synaptic estrogen receptors in hippocampal principal neurons. J Neurochem 100:950967. CrossRef Medline

Murakami G, Tsurugizawa T, Hatanaka Y, Komatsuzaki Y, Tanabe N, Mukai H, Hojo Y, Kominami S, Yamazaki T, Kimoto T, Kawato S (2006) Comparison between basal and apical dendritic spines in estrogen-induced rapid spinogenesis of CA1 principal neurons in the adult hippocampus. Biochem Biophys Res Commun 351:553558. CrossRef Medline

Murphy DD, Segal M (1997) Morphological plasticity of dendritic spines in central neurons is mediated by activation of CAMP response element binding protein. Proc Natl Acad Sci USA 94: 1482-1487. Medline
Nguyen TV, Yao M, Pike CJ (2009) Dihydrotestosterone activates CREB signaling in cultured hippocampal neurons. Brain Res 1298: 1-12. CrossRef Medline

Oberlander JG, Woolley CS (2016) 17beta-estradiol acutely potentiates glutamatergic synaptic transmission in the hippocampus through distinct mechanisms in males and females. $J$ Neurosci 36:2677-2690. CrossRef Medline

Oberlander JG, Woolley CS (2017) Correction: 17beta-estradiol acutely potentiates glutamatergic synaptic transmission in the hippocampus through distinct mechanisms in males and females. J Neurosci 37:12314-12327. CrossRef

O'Neill EE, Blewett AR, Loria PM, Greene GL (2008) Modulation of alphaCaMKII signaling by rapid ERalpha action. Brain Res 1222: 1-17. CrossRef Medline

Packard MG, Kohlmaier JR, Alexander GM (1996) Posttraining intrahippocampal estradiol injections enhance spatial memory in male rats: interaction with cholinergic systems. Behav Neurosci 110: 626-632. Medline

Romeo RD, McCarthy JB, Wang A, Milner TA, McEwen BS (2005) Sex differences in hippocampal estradiol-induced N-methyl-D-aspartic acid binding and ultrastructural localization of estrogen receptor-alpha. Neuroendocrinology 81:391-399. CrossRef Medline

Sandstrom NJ, Kim JH, Wasserman MA (2006) Testosterone modulates performance on a spatial working memory task in male rats. Horm Behav 50:18-26. CrossRef Medline

Sheppard PAS, Koss WA, Frick KM, Choleris E (2018) Rapid actions of oestrogens and their receptors on memory acquisition and consolidation in females. J Neuroendocrinol 30:e12485. CrossRef

Smejkalova T, Woolley CS (2010) Estradiol acutely potentiates hippocampal excitatory synaptic transmission through a presynaptic mechanism. J Neurosci 30:16137-16148. CrossRef Medline

Smith CC, McMahon LL (2006) Estradiol-induced increase in the magnitude of long-term potentiation is prevented by blocking NR2B-containing receptors. J Neurosci 26:8517-8522. CrossRef Medline

Snyder MA, Cooke BM, Woolley CS (2011) Estradiol potentiation of NR2B-dependent EPSCs is not due to changes in NR2B protein expression or phosphorylation. Hippocampus 21:398-408. CrossRef Medline

Spritzer MD, Gill M, Weinberg A, Galea LA (2008) Castration differentially affects spatial working and reference memory in male rats. Arch Sex Behav 37:19-29. CrossRef

Tanaka M, Sokabe M (2013) Bidirectional modulatory effect of $17 \beta$ estradiol on NMDA receptors via $\mathrm{ER} \alpha$ and $\mathrm{ER} \beta$ in the dentate gyrus of juvenile male rats. Neuropharmacology 75:262-273. CrossRef Medline

Tuscher JJ, Fortress AM, Kim J, Frick KM (2015) Regulation of object recognition and object placement by ovarian sex steroid hormones. Behav Brain Res 285:140-157. CrossRef Medline

Tuscher JJ, Luine V, Frankfurt M, Frick KM (2016a) Estradiolmediated spine changes in the dorsal hippocampus and medial prefrontal cortex of ovariectomized female mice depend on ERK and mTOR activation in the dorsal hippocampus. J Neurosci 36 : 1483-1489. CrossRef

Tuscher JJ, Szinte JS, Starrett JR, Krentzel AA, Fortress AM, RemageHealey L, Frick KM (2016b) Inhibition of local estrogen synthesis in the hippocampus impairs hippocampal memory consolidation in ovariectomized female mice. Horm Behav 83:60-67. CrossRef

Vázquez-Pereyra F, Rivas-Arancibia S, Loaeza-Del Castillo A, Schneider-Rivas S (1995) Modulation of short term and long term memory by steroid sexual hormones. Life Sci 56:PL255-PL260. Medline

Waters EM, Yildirim M, Janssen WGM, Lou WYW, McEwen BS, Morrison $\mathrm{JH}$, Milner TA (2011) Estrogen and aging affect the synaptic distribution of estrogen receptor beta-immunoreactivity in the CA1 region of female rat hippocampus. Brain Res 1379:86-97. CrossRef

Waters EM, Thompson LI, Patel P, Gonzales AD, Ye HZ, Filardo EJ, Clegg DJ, Gorecka J, Akama KT, McEwen BS, Milner TA (2015) G-protein-coupled estrogen receptor 1 is anatomically positioned 
to modulate synaptic plasticity in the mouse hippocampus. J Neurosci 35:2384-2397. CrossRef Medline

Zhao L, Chen S, Ming Wang J, Brinton RD (2005) 17beta-estradiol induces $\mathrm{Ca} 2+$ influx, dendritic and nuclear $\mathrm{Ca} 2+$ rise and subsequent cyclic AMP response element-binding protein activation in hippocampal neurons: a potential initiation mechanism for estrogen neurotrophism. Neuroscience 132:299-311. CrossRef Medline
Zhao Z, Fan L, Frick KM (2010) Epigenetic alterations regulate estradiol-induced enhancement of memory consolidation. Proc Natl Acad Sci USA 107:5605-5610. CrossRef Medline

Zhao Z, Fan L, Fortress AM, Boulware MI, Frick KM (2012) Hippocampal histone acetylation regulates object recognition and the estradiol-induced enhancement of object recognition. J Neurosci 32:2344-2351. CrossRef Medline 